\title{
O homem livre e pobre no Brasil oitocentista
}

\author{
Cristiano Luís Christillino
}

\section{SciELO Books / SciELO Livros / SciELO Libros}

CHRISTILLINO, AL. O homem livre e pobre no Brasil oitocentista. In: OLIVEIRA, TB., org. Trabalho e trabalhadores no Nordeste: análises e perspectivas de pesquisas históricas em Alagoas, Pernambuco e Paraíba [online]. Campina Grande: EDUEPB, 2015, pp. 57-84. ISBN 978-85-7879333-3. Available from SciELO Books $<$ http://books.scielo.org $>$.

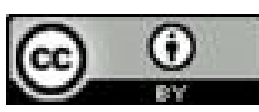

All the contents of this work, except where otherwise noted, is licensed under a Creative Commons Attribution 4.0 International license.

Todo o conteúdo deste trabalho, exceto quando houver ressalva, é publicado sob a licença Creative Commons Atribição 4.0.

Todo el contenido de esta obra, excepto donde se indique lo contrario, está bajo licencia de la licencia Creative Commons $\underline{\text { Reconocimento 4.0. }}$ 


\section{O homem livre e pobre no Brasil oitocentista}

\section{Cristiano Luis Christillino}

\section{INTRODUÇÁO}

A população conhecida como de homens livres e pobres era extensa no Século XIX, mas ainda conta com poucos trabalhos na historiografia. Trata-se de um grupo sobre o qual há poucas fontes. Muito se sabe sobre os escravos e seus senhores, mas ainda pouco sobre a imensa população de homens e mulheres livres espalhados pelas províncias do Império do Brasil. Os dados dos censos populacionais do Século XIX nos instigam a questionar sobre o predomínio da escravidão no Brasil rural oitocentista.

Em 1822, o Brasil tinha uma população entre 4,5 e 4,8 milhóes, e cerca de um terço seria escrava. Em 1850, teria chegado a, aproximadamente, 7,5 milhóes, com os escravos, o que respondia por algo em torno de $30 \%$ do total. O censo de 1872 revelaria 10,1 milhóes de habitantes, com a população escrava na casa de 1,5 milhão. Em 1886/87, às vésperas da abolição da escravidão, ainda havia pouco mais de 700 mil escravos. Nesse quadro, o Nordeste se apresentava como a regiáo mais populosa, com, aproximadamente, $47 \%$ da população total. Na Região Sudeste, havia cerca de $40 \%$, enquanto que o Sul teria pouco mais de $5 \%$, o Norte, $4 \%$, e o Centro-oeste, $3 \%$. Em 1872, dados censitários mostraram o Nordeste ainda com $46,6 \%$ da população 
do Império ${ }^{1}$. Logo, a regiấo cujas províncias eram mais populosas, entre elas, a Paraíba, cuja população escrava estava em franca diminuiçáo, devido ao tráfico interprovincial, apresentavam um importante quadro de pesquisa aos historiadores.

Conforme se pode observar no quadro abaixo, em 1874, o número percentual de escravos náo chegava aos $16 \%$, num contexto em que a Lei Eusébio de Queiroz, de 1850, freou o alargamento da escravidão via importação de escravos e, também, quando a Lei do Ventre Livre, de 1871, gerava seus primeiros impactos no crescimento vegetativo da populaçáo cativa. Ainda assim, esse índice mostra uma significativa transição da mão de obra escrava para a livre, e a expansão do grupo de trabalhadores aqui chamados de homens livres e pobres. As províncias do Rio de Janeiro e do Espírito Santo apresentaram um alto percentual de escravos em relação ao quadro geral de sua população, mas o mesmo índice não se confirmou nas demais províncias. No Rio Grande do Sul, esse percentual atingiu apenas $21 \%$, e nas províncias do Nordeste, era ainda menor.

Quadro 1: Províncias com maior proporção de população escrava -1874

\begin{tabular}{|l|l|l|l|l|}
\hline Província & $\begin{array}{l}\text { Pop u la çã o } \\
\text { livre }\end{array}$ & $\begin{array}{l}\text { População } \\
\text { escrava }\end{array}$ & Total & $\begin{array}{l}\text { Percentual de } \\
\text { escravos }\end{array}$ \\
\hline RJ & 456.850 & 301.352 & 758.202 & 39,7 \\
\hline ES & 59.748 & 22.297 & 81.775 & 27,6 \\
\hline RS & 364.002 & 98.450 & 462.452 & 21,3 \\
\hline MA & 284.101 & 74.598 & 358.699 & 20,8 \\
\hline SP & 680.742 & 174.622 & 855.364 & 20,4 \\
\hline SE & 139.812 & 33.064 & 172.872 & 19,1 \\
\hline MG & 1.642 .449 & 311.304 & 1.953 .753 & 15,9 \\
\hline Brasil & $\mathbf{8 . 2 2 0 . 6 2 0}$ & $\mathbf{1 . 5 4 0 . 8 2 9}$ & $\mathbf{9 . 7 6 1 . 4 4 9}$ & $\mathbf{1 5 , 8}$ \\
\hline
\end{tabular}

Fonte: DIRETORIA GERAL DE ESTATÍSTICA. Relatórios de trabalhos estatísticos. Rio de Janeiro, 1875, p. 46-62. In: Relatório do Ministério da Agricultura, 10 de maio de 1883, apud ZARTH, op. cit., 2002, p. 109.

1 ABREU, Marcelo de Paiva; LAGO, Luiz Aranha Correa do. A economia brasileira no Império 1822-1889. Rio de Janeiro: Texto para discussáo n. 584 - Departamento de Economia, PUC-Rio, novembro de 2010. 
Se a média brasileira de escravos, no quadro geral da população, não ultrapassou $16 \%$ do seu contingente total, quem eram os $84 \%$ restantes de homens livres? É difícil precisar as ocupaçôes desse enorme contingente populacional, mas, certamente, a maioria desse grupo estava concentrada no meio rural, trabalhando nas lavouras e nas criaçóes voltadas para o abastecimento interno. Assim, neste capítulo, discutiremos sobre as atividades desse grupo, naquela sociedade em transformação, e sobre a documentação existente sobre eles.

\section{O homem livre e pobre na historiografia}

Em alguns trabalhos da historiografia, o ambiente rural do Brasil oitocentista é descrito com base em seu 'pequeno número de habitantes'. Somente nos passam informações sobre alguns poucos fazendeiros e seus escravos nas freguesias daquele período. Quando se fala nas grandes fazendas ou em exploraçóes agropecuárias, náo se pergunta quem trabalhava nelas além dos escravos. E quando se analisam as fazendas ou sesmarias abandonadas, especialmente nas províncias do Sul, para onde iriam aqueles que ali trabalhavam? Acompanhariam eles os seus patróes como um pertence qualquer? Não teriam condiçóes de permanecer nos locais onde moravam produzindo sua subsistência? Seriam essas fazendas habitadas apenas por seus donos? Certamente havia outros habitantes além dos escravos e de 'alguns intrusos'. O próprio número expressivo de comandantes da Guarda Nacional, nos diferentes municípios do Império, já aponta para o grande número de pessoas 'comandadas' ou ainda 'protegidas' daqueles. Nesse sentido, Hebe de Castro chamou à atenção dos historiadores para o grande número de pequenos e médios lavradores existentes nas áreas de ocupaçôes antigas no Rio de Janeiro, nas quais a desconcentração da estrutura fundiária criou condiçóes para a existência desse grupo como "pequenos proprietários".

A própria estrutura produtiva brasileira do Século XIX aponta para uma ampla diversificação agrícola, cujas atividades não se baseavam apenas na mão de obra escrava e, muitos menos, na

2 CASTRO, Hebe Maria Mattos de. Ao sul da história: lavradores pobres na crise do trabalho escravo. São Paulo: Brasiliense, 1986. 
plantation exportadora. João Luís Fragoso nos mostra que, apesar da importância das lavouras de exportação no contexto internacional da época, havia uma significativa acumulaçáo endógena realizada pela agricultura voltada para o abastecimento interno e, principalmente, pelo comércio ligado a essa atividade ${ }^{3}$. $\mathrm{O}$ abastecimento tinha um peso tal na economia do Brasil, nos períodos colonial e imperial, que, muitas vezes, era o capital obtido nessas atividades que garantia o ingresso dos fazendeiros na agricultura exportadora. Dessa forma, as produçóes coloniais tinham uma relativa autonomia em relação ao mercado internacional. $\mathrm{O}$ abastecimento interno, embora utilizasse a máo de obra escrava, era realizado, principalmente, pelos lavradores livres. E essa atividade tinha capacidade de gerar riquezas tanto quanto ou, até mesmo, mais do que as produçóes agroexportadoras, os lavradores livres se integravam ao "mercado colonial", como refere Fragoso. Isso mostra a importância econômica e numérica desse grupo naquele período.

As duas obras clássicas sobre o grupo de 'homens livres e pobres nacionais' consagraram a visão de sua desintegração da vida econômica e política da sociedade brasileira no Século XIX e no início do Século XX. Maria Sylvia de Carvalho Franco ${ }^{4}$ analisou esse grupo social no Século XIX. A autora defendeu que a violência cotidiana entre esses homens era o subterfúgio à sua falta de mobilidade social. A escravidão teria deixado os homens livres e pobres "sem razão de ser" naquela sociedade. Antônio Cândido, por sua vez, estudou o "caipira" paulista nas décadas de 1940 e 1950. Em sua concepção, os homens pobres do campo tinham uma cultura pobre, que "não foi feita para o progresso: a sua mudança é o seu fim". A falta de estímulos e de técnicas produtivas teria causado o seu "desapego ao trabalho". A obra de Antônio

3 FRAGOSO, João Luís. Economia brasileira no Século XIX: mais do que uma plantation escravista-exportadora. In: LINHARES, Maria Yedda (org.). História geral do Brasil. Rio de Janeiro: 2.ed., Ed. Campus, 1996.

4 FRANCO, Maria Sylvia de Carvalho. Homens livres na ordem escravocrata. São Paulo: Kairós, 1983.

5 CÂNDIDO, Antônio. Os parceiros do Rio Bonito: estudo sobre o caipira paulista e a transformaçấo dos seus meios de vida. Rio de Janeiro: José Olympio Editora, 1964, p. 82. 
Cândido, apesar de centrar sua análise em meados do Século XX, é uma referência para os trabalhos sobre o homem livre e pobre no Século XIX. Laura de Souza e Mello, analisando a população marginal da atividade mineradora em Minas Gerais no período colonial, afirmou:

Criava-se um círculo vicioso: o sentimento de estranheza ante um sistema que não o abrigava tolhia no desclassificado a possibilidade de se identificar com o seu semelhante, e o lançava na violência; essa, por sua vez, opunha-o a seu semelhante, e impedia o crescimento da consciência de grupo [...] a possibilidade de se transformar em carrasco de seu semelhante subentendia o congelamento da consciência de grupo ${ }^{6}$.

Assim, os primeiros trabalhos sobre os homens livres pobres, da mesma forma que sobre os 'desclassificados', projetaram-lhes um perfil violento, mas, ao mesmo tempo, passivo diante de sua exploração. Essa visão foi contestada nos anos 1980, especialmente pelos trabalhos desenvolvidos no Programa de Pós-graduação em História da Universidade Federal Fluminense. Principalmente sob a orientação de Maria Yedda Linhares e de Ciro Flamarion Cardoso, foram produzidas várias dissertaçóes e teses a respeito do tema, a maioria baseada na história social da segunda geraçáo dos Annales. Eles mostraram a complexidade do mundo rural brasileiro dos Séculos XIX e XX, salientando que a estrutura fundiária era mais diversa do que a apresentada naqueles primeiros trabalhos, e também demonstraram a falta de embasamento empírico para a generalização da 'realidade agrária' daquele período. Para isso, os trabalhos dessa geração se basearam, sobretudo, no método quantitativo. Já na década de 1990, houve uma terceira etapa dos estudos sobre os 'homens livres pobres' no Brasil: o enfoque se deu sobre suas resistências frente ao processo

6 SOUZA, Laura de Mello e. Desclassificados do ouro: a pobreza mineira no Século XVIII. Rio de Janeiro: Ediçóes Graal, 1982, p. 217. 
de expropriação. Nessa última etapa, Márcia Motta trouxe uma importante contribuição, ao analisar o direito agrário do Século XIX, mostrando que os pequenos posseiros também se valeram da legislaçáo para efetivar suas posses e fazer frente aos litígios contra os grandes possuidores de terras ${ }^{7}$. Esse trabalho também instigou outras pesquisas em torno da resistência camponesa no Brasil. Embasadas na obra de Thompson, essas investigaçóes procuraram desconstruir a amnésia social que paira no homem livre e pobre nos períodos anteriores às ligas camponesas ${ }^{8}$.

Ao mesmo passo em que formaram um grupo extenso naquele período, os "homens livres e pobres" apresentaram uma enorme complexidade em sua organizaçáo social, o que não nos permite traçar um perfil seguro deles. Utilizamos o termo homem livre e pobre, por ser o mais apropriado para defini-lo, na medida em que é mais abrangente do que as designaçóes caipira e caboclo. Nessa 'categoria', podem ser enquadrados lavradores com títulos de suas terras, agregados, 'dependentes', posseiros de terras 'devolutas', entre outros. Eles eram, principalmente, descendentes de portugueses, africanos e indígenas e já estavam integrados àquela sociedade no momento da chegada dos imigrantes europeus destinados às colônias oficiais e particulares, a partir de meados do Século XIX, mas também formados por ex-escravos, degredados dos mais variados tipos e de 'migrantes' de outras províncias. As áreas florestais da Província de São Pedro do Rio Grande do Sul, por exemplo, foram ocupadas, antes da imigração alemã, tanto pelos tropeiros do Sudeste quanto pelos açorianos, quilombolas e libertos e pela integraçáo deles com os nativos?.

No Nordeste este grupo foi ainda maior. Regiáo de ocupação mais antiga em relação ao Centro-Sul, o número de famílias livres e pobres era extenso no século XIX. A estrutura fundiária mais

7 MOTTA, Márcia. Nas fronteiras do poder: conflito e direito a terra no Brasil do Século XIX. Rio de Janeiro: Arquivo Público do Estado do Rio de Janeiro; Vício de Leitura, 1998.

8 MOTTA, Márcia Maria Menendes. Jogos da memória: conflitos de terra e amnésia social. In: Tempo, no 6, p. 183-198, 1998.

9 CHRISTILLINO, Cristiano Luís. Estranhos em seu próprio cháo: o processo de apropriaçôes e expropriaçôes de terras na Província de São Pedro do Rio Grande do Sul (o Vale do Taquari no período de 1840-1889). São Leopoldo: Dissertação de Mestrado em História/ UNISINOS, 2004. 
antiga permitiu a expansão deste grupo que não tinha acesso à terra ou de pequenos proprietários, que precisavam vender a sua mão de obra como uma fonte de complementação de renda. Além disso, as secas também provocavam um grande afluxo de pessoas à Zona da Mata. Na presidência da Bahia, Cansanção de Sinimbú encaminhou a criação da Colônia Salto do Rio Pardo, no Município de Canavieiras, para abrigar as pessoas que se refugiavam da seca $^{10}$. Processo similar ocorreu na Zona da Mata de Pernambuco, quando a população que migrava durante as secas do Agreste e, em especial do Sertáo, formava excedentes populacionais que preocupavam os presidentes de província. Nisso, destacam-se as secas entre 1877 e 1879. Nesse período, foram criadas as colônias Socorro, na Zona da Mata e a Riacho do Matto, esta no Agreste, com 1.100 famílias, para a fixação de retirantes. Em 1878, em torno de 60 mil pessoas afluíram para a capital pernambucana e seus arredores ${ }^{11}$. Por esta razão a criação de colônias de imigrantes em regime de parceria, para o fornecimento de mão de obra para as fazendas, não esteve no centro das atençóes dos fazendeiros da Zona da Mata no Nordeste.

Complexo quanto à sua definição, heterogêneo em relação à sua formação, os homens livres e pobres ainda nos trazem outro aspecto que mostra sua amplitude: o nível de 'fortuna' dos seus componentes. Os integrantes desse grupo, apesar de a maioria ser desvalida, eram trabalhadores rurais sem terra e pequenos e médios possuidores de terras que, muitas vezes, tinham escravos. Havia casos em que os lavradores nacionais vendiam sua força de trabalho aos seus semelhantes, como uma forma de ganho complementar. Essa é mais uma característica contraditória daquele grupo, que não produz uma relação predominantemente assalariada, mas não deixa de ser uma necessidade estrutural dele ${ }^{12}$. Nesse sentido, observando o contexto inglês do Século XVIII, E. P. Thompson já afirmara que

10 GONÇALVES, Graciela Rodrigues. As secas na Bahia do século XIX. Dissertação de Mestrado em História/UFBA, 2000.

11 Relatório do presidente da Província de Pernambuco de 1879.

12 WANDERLEY, Maria de Nazareth Baudel. Raízes históricas do campesinato brasileiro. In: tyGyAnais do XX Encontro Anual da ANPOCS, Caxambu, 1996. 
O trabalho remunerado na colheita e nas épocas de maior atividade, os ofícios ou empregos secundários se suplementavam uns aos outros para criarem o sustento necessário. A subsistência não era nada além de mísera, o modo de vida podia ser instável, mas os indivíduos não estavam sujeitos a uma disciplina alienada de trabalho desde a juventude até a sua morte ${ }^{13}$.

Como nos lembra Thompson, a venda temporária de trabalho pelos lavradores pobres (camponeses usufruidores dos direitos comuns florestais, no caso da Inglaterra), além de garantir o sustento desse grupo em épocas de carestias, assegurava-lhe condiçôes para permanecer no meio onde estava inserido. $\mathrm{O}$ termo homem livre e pobre, portanto, é complexo, controverso e engloba uma importante parcela da população do Brasil Império.

\section{O homem livre e pobre na Província de Sáo Pedro do Rio Grande do Sul \\ O Rio Grande do Sul é um dos estados onde a temática dos} homens livres e pobres recebeu um maior número de trabalhos. Paulo Zarth, em seus trabalhos pioneiros sobre esses homens livres e pobres do Século XIX, mostrou que os integrantes desse grupo não estavam social e economicamente isolados naquele contexto, tampouco afastados dos mercados locais ${ }^{14}$. Zarth demonstrou que a principal atividade desse grupo, no Rio Grande do Sul, estava na produção da erva-mate, o que permitiu a criação de sólidas relaçóes com o mercado provincial. Nesse sentido, o autor defende que a maioria dos "ervateiros", cujo trabalho era sazonal, poderia ser enquadrada como camponeses. No que diz respeito à segunda metade do Século XIX, Luís Augusto Farinatti

13 THOMPSON, Edward Palmer. Costumes em comum. São Paulo: Cia. das Letras, 1998, p. 144.

14 ZARTH, Paulo Afonso. Do arcaico ao moderno: as transformaçôes do Rio Grande do Sul rural no Século XIX. Ijuí: Ed. da Unijuí, 2002; ZARTH, Paulo Afonso. História agrária do Planalto Gaúcho (1850-1920). Ijuí: Fidene-Unijuí, 1997. 
analisou os homens livres e pobres no município de Santa Maria, mostrando a complexidade da estrutura agrária nessa localidade e a importância desse grupo sobre a agricultura de alimentos ${ }^{15}$. Nesse mesmo sentido, Arlene Foletto mostrou a importância social desse grupo em Itaqui, onde, aparentemente, era predominante o grande latifúndio pecuarista. Foletto também mostrou uma arena de conflitos que envolvia os homens livres e pobres ${ }^{16}$. Já Graciela Bonassa Garcia analisou o processo de ocupação da terra no município de Alegrete, destacando a apropriação irregular de terras pela elite fundiária local. Garcia também mostrou a arena de disputas travadas pelos homens livres pobres, frente à expansão do latifúndio pecuarista na regiáo da Fronteira da entáo Província de Sáo Pedro ${ }^{17}$. Abordando a regiáo do Alto Rio dos Sinos, Dóris Fernandes Magalhães mostrou a estrutura agrária complexa e dinâmica das áreas onde foram criadas as primeiras colônias de imigraçáo do Rio Grande do Sul, em que a pequena propriedade antecedeu a colonização ${ }^{18}$. Magalhães também analisou a presença dos homens livres e pobres nas áreas de colonização nos vales do Caí e Sinos.

Em minha dissertaçáo de Mestrado ${ }^{19}$, mostrei que os ervateiros formaram um grupo social extenso no Século XIX ${ }^{20}$, constituído por homens pobres, dedicados à extraçáo da erva-mate que, na maioria dos casos, não possuíam a posse formal de suas terras. Sua origem social era heterogênea, pois eram agricultores e

15 FARINATTI, Luís Augusto Ebling. Sobre as cinzas da mata virgem: lavradores nacionais na Província do Rio Grande do Sul (Santa Maria, 1845-1880). Porto Alegre: Dissertação de Mestrado em História/PUCRS, 1999.

16 FOLETTO, Arlene Guimarães. Dos campos junto ao Uruguai aos matos de Cima da Serra: a paisagem agrária na Paróquia de São Patrício de Itaqui (1850-1889). Porto Alegre: Dissertação de Mestrado em História/UFRGS, 2003.

17 GARCIA, Graciela Bonassa. Terra, trabalho e propriedade: a estrutura agrária da campanha rio-grandense nas décadas finais do período imperial (1870-1890). Rio de Janeiro: Tese de Doutorado em História/UFF, 2010.

18 MAGALHÂES, Dóris Rejane Fernandes. Terras, senhores, homens livres, colonos e escravos na ocupação da fronteira no Vale dos Sinos. São Leopoldo: Tese de Doutorado em História/UNISINOS, 2003.

19 CHRISTILLINO, Cristiano Luís. Estranho..., op. cit.

20 Conforme apontam os processos de legitimação de terras, a correspondência das Câmaras de Vereadores, os processos-crime, os relatórios de presidentes de província e as memórias de época. 
agregados que migravam em busca de alternativas para a pressão fundiária das áreas próximas às vilas e das lavouras de parceria das fazendas locais por escravos fugitivos e por um grande número de foragidos da justiça. Os ervais se consagraram como um local de refúgio, especialmente durante a Farroupilha, quando muitos combatentes farrapos se refugiaram nos ervais da regiáo serrana do Baixo Jacuí. Em Taquari, o ingresso de combatentes nos ervais ocorreu, principalmente, após o combate de Santo Amaro, em 1837. Os ervateiros são marcados pela diversidade étnica. Popularmente conhecido como caboclo, esse grupo é marcado pelo encontro entre o negro e o branco com o indígena. Uma boa parte dos homens que migrava para os ervais constituiu famílias com as "bugras mansas". Além disso, muitos fazendeiros empregaram os ervateiros em suas terras. Alguns lhes pagavam dois terços do total de erva-mate colhida, enquanto, nos ervais mais ricos em Ilex Paraguariensis, a máo de obra era contratada por jornada. Entretanto, a maioria dos ervais estava localizada em terras públicas.

A extração de erva-mate, em ervais nativos, era predatória. Isso fazia com que uma boa parte das árvores fosse destruída em poucas safras, o que exigia uma constante migração para novas áreas. Essa atividade era consorciada com a lavoura de subsistência, da qual saíam alguns produtos para os mercados mais próximos. Alguns se tornaram posseiros, cultivando lavouras de alimentos nas áreas florestais, outros chegaram a acumular algum patrimônio ${ }^{21}$. A venda da erva-mate e de outros produtos extrativos e agrícolas foi o elo entre esse grupo de homens livres e pobres e o mercado. Uma boa parte do grupo constituiu posses que estariam amparadas pela Lei de Terras de 1850. Da mesma forma, muitos carijos (jirau no qual se beneficiava a erva) formaram servidóes públicas ou áreas de uso comum pelos seus trabalhadores, pois eles também estavam assegurados por aquela legislação. Embora a Lei de Terras tivesse transformado, a partir de 1850, o posseiro em invasor, também assegurava a ocupação efetivada até então. Em meados do Século XIX, as áreas florestais estavam preocupando

21 É o que mostra FARINATTI, Luís Augusto, op. cit. 
as autoridades públicas em relação à "segurança de propriedade e da tranquilidade pública”.

As determinaçôes da Justiça e da polícia não tinham um longo alcance no mato, no qual, inclusive, havia condiçóes para a sobrevivência de grupos à margem das práticas sociais prescritas pelo Estado, o que aumentava o temor em torno das áreas florestais, especialmente, entre os imigrantes e as elites locais. A própria literatura de época nos mostra a representação do gaúcho como o centauro dos pampas ou, ainda, o senhor das estâncias, mas não faz referências ao universo social existente em torno das áreas florestais. Euclides da Cunha, em sua obra Os sertóes, aborda esse aspecto, mencionando a facilidade oferecida pela natureza para o "gaúcho", montado em seu cavalo, ser respeitado em suas áreas campeiras, pois não teria que enfrentar as incertezas apresentadas pelas matas ${ }^{22}$. O "gaúcho" seria herói em campo aberto, mas não tinha a mesma 'primazia' no mato, onde náo se poderia enxergar o inimigo a quilômetros.

De difícil acesso e repleto de obstáculos, o mato ainda apresentava outro problema aos aparelhos ou grupos repressivos: as redes de relaçóes pessoais e de solidariedade que envolviam seus habitantes. Aquele universo social era complexo e envolvia vários grupos diferenciados entre si. Os trabalhadores da extração de erva-mate eram pobres, e muitos deles, refugiados. Existia uma ligação entre eles e o universo circundante ao mato ${ }^{23}$. As alianças e as relaçóes sociais existentes entre os homens que migravam para os ervais e as famílias neles existentes ou mesmo as suas próprias permitiram refúgios seguros àqueles, bem como certa margem às suas açóes.

As terras florestais, na Província de São Pedro do Rio Grande do Sul, também asseguravam a coleta de frutas e outros alimentos silvestres presentes na flora local, rica e abundante, um variado número de caças e pescas, que permitiam uma importante fonte complementar de proteína, além de terras virgens de grande

22 CUNHA, Euclides. Os Sertóes - v. 2: Campanha de Canudos. São Paulo: Aguillar, 1966.

23 RIBEIRO, José Iran. Quando o serviço os chamava: milicianos e guardas nacionais no Rio Grande do Sul (1825-1845). Santa Maria: Editora da UFSM, 2005. 
fertilidade para a agricultura de subsistência. Uma vez que o cultivo nos roçados garantia o fornecimento de alimentos e eventuais excedentes para a venda nos comércios locais, a atividade que propiciava um ganho maior a esses homens livres era a extração do mate, amplamente difundida nas áreas florestais sul-rio-grandenses. Houve, assim, um consórcio da erva-mate com a agricultura de subsistência. Esses trabalhadores, geralmente, arranchavam-se nos ervais, visto que sua dispersão sobre as áreas florestais fazia com que os 'ervateiros' se dirigissem até os locais de sua incidência. São vários os indícios que comprovam a ampla participação deles nessa atividade. A própria importância crescente da erva -mate na economia provincial já nos mostra a incidência de tal grupo sobre os ervais sul-rio-grandenses. Isso quando quase toda a erva-mate era contrabandeada sem que se pagassem impostos e, por causa disso, não eram contabilizadas nas arrecadaçôes, o que nos impede de mostrar o seu volume total.

Além da expressividade econômica da erva-mate, especialmente na década de 1850 , quando se tornou o segundo produto mais exportado da Província ${ }^{24}$, a análise das atividades comerciais do Rio Grande do Sul também denota o peso da estrutura de produção voltada para o abastecimento interno, algo que reforça a importância econômica dos homens livres e pobres naquele período. Cláudia Munhoz, analisando a Associação Comercial de Rio Grande, demonstra a importância dos gêneros alimentícios nos volumes totais das exportaçôes da Província de São Pedro do Rio Grande do Sul ${ }^{25}$. Como o Porto de Rio Grande era o principal ponto de escoamento da produção da Província, sua movimentação traz um bom perfil de suas atividades produtivas. Munhoz mostrou que a produção de gêneros para o abastecimento interno era anterior à imigração alemã. A agricultura de alimentos abrangia tanto as grandes, as médias e as pequenas 'propriedades' quanto as pequenas posses nas áreas florestais, que

24 Relatório do presidente da Província do Rio Grande do Sul de 1859.

25 MUNHOZ, Cláudia. A Associaçáo Comercial do Rio Grande de 1844 a 1852: interesses e atuação representativa do setor mercantil. Sáo Leopoldo: Dissertaçáo de Mestrado em História/UNISINOS, 2003. 
eram amplamente difundidas, mas deixou apenas indícios de sua existência. A abertura da estrada ligando Santa Cruz a Soledade é um bom exemplo desses indícios.

Assim, na década de 1880, foi construída uma estrada entre os recém-criados municípios de Santa Cruz e o de Soledade, cortando os ervais da Serra Geral do Município de Estrela. As legitimaçôes dessas áreas mostram, em seus mapas, vários 'caminhos para os matos devolutos'. Essas vias oferecem indícios da existência dos homens livres e pobres nas áreas serranas, pois eles eram dirigidos às pequenas posses localizadas no interior dos ervais. Os mapas indicam, ainda, os vários "fabricos de erva-mate" - cerca de três a cinco em cada área legitimada. Ressalte-se, porém, que não eram empregados escravos em larga escala nessas atividades, elas eram realizadas por homens livres pobres, porque os ervais eram uma atividade extrativa, e a Lei de Terras de 1850 só assegurava a legitimação das posses realizadas em terras devolutas, com a exploração agropecuária. Assim, as pequenas posses dos homens livres e pobres foram apropriadas de forma ilegal ${ }^{26}$.

Os mapas presentes nos processos de legitimação também mostram que a estrada aberta entre Santa Cruz e Soledade separava algumas fazendas dos "matos devolutos". Numa época em que havia verdadeiras disputas pela localização das estradas públicas e ainda existiam diversos "caminhos para os matos devolutos", certamente havia um grande número de posses naquelas áreas, pois, além da prática de se estabelecerem estradas a partir de caminhos já existentes, elas, geralmente, eram construídas em locais povoados devido à insegurança provocada pelas matas. Dificilmente existiria uma estrada, ou caminho reconhecido como tal, em meio aos matos devolutos (desabitados e inexplorados). Os próprios caminhos existentes nas "matas devolutas" já mostram o seu pleno povoamento ainda no período anterior à colonização. Os mapas, apresentados nos processos de legitimação de terras, provam a existência de homens livres e pobres nas áreas consideradas,

26 CHRISTILLINO, Cristiano Luís. Litígios ao sul do Império: a Lei de terras e a consolidação política da Coroa no Rio Grande do Sul (1850-1880). Niterói: Tese de Doutorado em História/UFF, 2010. 
até então, como "devolutas".

A insegurança das matas era causada, principalmente, pela presença expressiva de refugiados, quilombolas e "índios bra$\operatorname{vos}^{\prime 27}$. As memórias locais são ricas em dados que confirmam essa hipótese. Ernest Janfrüchte foi um pastor alemão que atuou na Colônia Teutônia no período de 1869 a 1872 . Ele registrou a existência, em suas proximidades, de uma fazenda que utilizaria 380 escravos, que, apesar de um pouco exagerado para o contexto, indica um grande ajuntamento de trabalhadores cativos e livres em torno de uma colônia imigrante. Nas palavras de Janfrüchte, isso causava temor aos colonos, assim como a presença de quilombos nas proximidades da estrada que ia de Taquari a Colônia Teutônia. O Pastor Janfrüchte também falou dos perigos enfrentados com os indígenas presentes naquela área, que teriam provocado ameaças em, pelo menos, duas ocasióes ${ }^{28}$. Essa memória de época exemplifica o contexto de insegurança vivido pelas colônias imigrantes. Guido Lang $^{29}$, por sua vez, afirmara que escravos fugitivos fundaram quilombos na área em que foi criada a Colônia Teutônia (1858). Também havia outros habitantes naquele lugar, uma forte presença indígena na região, o que provocava vários conflitos entre os nativos e a população local.

Esses grupos representavam uma ameaça às apropriaçóes de terras por parte da elite agrária. Assim, a 'abertura' da fronteira fundiária aos homens livres e pobres teve a importante função de afastar e, em muitos casos, integrar aqueles grupos às sociedades locais. É o mesmo que concluíra Warren Dean, ao analisar o caso de Rio Claro no interior de São Paulo:

Os donatários das sesmarias, portanto, tomaram conta dos melhores solos em Rio Claro sem a necessidade de recorrer a muita violência.

27 CHRISTILLINO, Cristiano Luís, Estranho..., op. cit.

28 DREHER, Martin N. \& ALTMANN, Friedholt. Os primórdios da Colônia Teutônia no Rio Grande do Sul. In: Estudos Leopoldenses, Série História, vol. 2, n. 2, p. 149-165, 1998.

29 LANG, Guido. A Colônia Teutônia: história e crônica (1858-1908). São Leopoldo: Rotermund, 1992. 
Mesmo quando se retiravam os caboclos prestavam um serviço ao regime das grandes lavouras. Ao se deixarem empurrar sempre mais no sentido das terras virgens que ficavam entre os aborígenes e as fazendas, os caboclos desempenhavam uma função de inestimável valor- ainda que não reconhecida- de manter os índios à distância. As lavouras de Rio Claro não eram atacadas por eles, ainda que a isso estivessem expostas, e não fossem protegidas pela milícia. Somente os caboclos sofriam represálias pela tomada das terras dos indígenas. Além disso, os grandes proprietários ficavam a salvo da hostilidade dos caboclos, pois esses descarregavam suas frustraçooes em cima do mais acessível de seus inimigos, e desprezavam os índios tanto quanto os fazendeiros os desprezavam ${ }^{30}$.

As constataçôes de Warren Dean podem ser aplicadas no vale do Taquari, onde é perceptível a utilizaçáo do homem livre e pobre como um "escudo humano" frente aos indígenas. Se existia uma fronteira agrária aberta na região, era, principalmente, devido à insegurança existente no mato, tanto por causa dos possíveis ataques dos indígenas quanto de foragidos e outros grupos que perambulavam pela região. Nos mapas dos autos de mediçóes da Lei de Terras de 1850, podemos visualizar essa estratégia, na medida em que as áreas legitimadas, com frequência, apresentavam "pequenos roçados" em suas bordas, geralmente próximas aos ervais que, certamente, não eram cultivados por seus legitimantes, os quais, na maioria dos casos, sequer moravam nas fazendas na Serra Geral. Assim, utilizavam-se das posses dos homens livres e pobres para legitimar suas áreas, colocando-os nos limites de suas "posses" para assegurar o seu "domínio". Dessa forma, os homens livres e pobres iam desbravando a mata, trabalhando nos seus

30 DEAN, Warren. Rio Claro: um sistema brasileiro de grande lavoura - 1820-1920. Rio de Janeiro: Paz e Terra, 1987, p. 32. 
roçados, construindo habitaçóes (os "ranchos") e abrindo caminhos e clareiras, o que seria fundamental para a exploraçáo das riquezas florestais, especialmente a erva-mate. Essa progressiva integraçáo das matas à sociedade local era uma forma de valorizar as terras, uma vez que eram criados os acessos, muitos dos quais eram aproveitados pelos fazendeiros e colonizadores, e era garantida sua segurança, com o afastamento dos indígenas e dos refugiados, além de sua integraçáo, em alguns casos.

$\mathrm{O}$ homem livre e pobre precisa ser visualizado com base em suas duas faces naquela sociedade. De um lado, o grupo desempenhou um importante papel para a elite fundiária local, através da apropriação de terras, em sua integração econômica, mas, de outro lado, eles também foram vistos com desconfiança na época. O Governo Imperial, de maneira geral, não confiava nos homens livres e pobres para se estabelecerem em núcleos coloniais, especialmente pelos laços e pelas relaçóes de dependência existente eles e a elite latifundiária sul-rio-grandense, os quais, uma vez assentados em lotes coloniais, não permitiriam a criação de uma base social alternativa aos estancieiros sul-rio-grandenses. Os latifundiários, por sua vez, viam os homens livres e pobres com preocupação, devido à sua crescente resistência ao avanço dos fazendeiros sobre as pequenas posses no interior de terras públicas e por seus elos de aliança com os grupos "inimigos da paz e do sossego público". Nesse sentido, os grandes fazendeiros viam com bons olhos a imigração, que "levaria a civilização às matas". Essa seria uma das razóes principais por que os 'homens ilustrados' da Província de Sáo Pedro do Rio Grande do Sul defenderam a imigração, e não, apenas, em função de uma "atitude fundamentada numa concepção moderna" ${ }^{31}$. Dessa forma, ambas as partes defenderiam a colonização das áreas florestais por imigrantes europeus, visando ao controle social das mesmas áreas.

Em contrapartida, os homens livres e pobres sofreram com o avanço do latifúndio e da colonização, mas sua trajetória náo foi marcada apenas por exclusão e submissáo. Esse grupo

31 CARDOSO, Fernando Henrique. Capitalismo e escravidáo no Brasil meridional: o negro na sociedade escravocrata do Rio Grande do Sul. Rio de Janeiro: Paz e Terra, 1977. 
empreendeu uma série de atos e estratégias que permitiram barrar em muitos casos esse processo.

\section{O homem livre e pobre e a resistência ao avanço do latifúndio e da colonizaçáo}

Inicio a discussáo sobre a resistência do homem livre e pobre a partir aplicabilidade do conceito de classe a esse grupo.

Adotamos aqui a noção de classe de Edward Thompson, que a concebe como um processo histórico baseado na experiência de homens e mulheres em suas relaçóes sociais. A consciência e a classe, propriamente ditas, seriam a última etapa desse processo. Náo creio que os ervateiros do Rio Grande do Sul, na segunda metade do Século XIX, tenham constituído uma classe, segundo a acepção de Thompson, na medida em que sua ação não era orientada por uma consciência de classe que direcionasse a trajetória do grupo. Isso porque "uma classe não pode existir sem um tipo qualquer de consciência de si mesma" ${ }^{32}$. Mas as relaçóes sociais dos ervateiros do Planalto e da Serra apontam para outra categoria privilegiada por Thompson, a experiência de classe, que ocorre quando sua resistência à expropriação de suas posses permite a postergação ou até mesmo sua suspensão, embora não tenham constituído um movimento social mais amplo. Esse é um processo que se assemelha à ação dos camponeses ingleses na defesa dos costumes ${ }^{33}$. Em Senhores e caçadores, Thompson pesquisou o banditismo rural na Floresta de Windsor, analisando a resistência dos camponeses ingleses à privatização de suas áreas comunais e à repressão em torno das caças ${ }^{34}$. Os camponeses ingleses também se valeram da interpretação do direito consuetudinário para garantir a retardação dos cercamentos dos campos naquela regiáo no Século XVIII. Na Inglaterra, eles utilizaram, além dos motins, a via do direito para assegurar os costumes comuns, em que estava baseada a preservaçáo de suas áreas comunais. Segundo

32 THOMPSON, Edward Palmer. As peculiaridades dos ingleses e outros artigos. Campinas: Ed. da UNICAMP, 2001, p. 279.

33 THOMPSON, Edward Palmer. Senhores e caçadores: a origem da Lei Negra. Rio de Janeiro: Paz e Terra, 1987.

34 Ibidem, op. cit. 
Thompson, "a resistência era mais rabugenta do que vibrante" 35 , mas contribuiu para postergar algumas transformaçóes capitalistas no campo.

Nessa perspectiva, Márcia Motta analisou a resistência dos pequenos posseiros, no Brasil, no Século XIX, e mostrou outro panorama da luta pela terra, ao discutir sobre as estratégias de afirmação de propriedade desse grupo ${ }^{36}$. Motta demonstrou que o homem livre e pobre não foi passivo diante do processo de exclusão da terra imposto pelos grandes fazendeiros. Os pequenos posseiros também utilizaram o meio jurídico para lutar por suas ocupaçóes, buscando brechas na Lei de Terras de 1850 para legitimá-las. Esse trabalho inaugurou uma nova visão sobre o campesinato no Brasil e evidenciou que a resistência desse grupo social é bem anterior ao surgimento das ligas camponesas iniciadas na década de 1950.

Os pequenos posseiros e ervateiros estabelecidos nas áreas florestais do Rio Grande do Sul, por sua vez, além de alguns conflitos e processos contra os fazendeiros locais, contaram com a via política para se opor à expropriação de suas terras, como foi o caso dos moradores dos ervais da povoação de Santa Bárbara. Localizada no ponto mais distante do município de Taquari, foi uma das últimas regióes apropriadas na Província, para a qual se deslocou um grande número de homens livres e pobres, atraídos pelos ricos ervais dessa localidade. Muitos colonizadores de Taquari adquiriram terras ao norte das primeiras colônias, como Raphael Azambuja, Bento Rosa e a Schilling e Cia, com o objetivo de garantir a formação de reservas fundiárias à expansão do complexo colonial. Antônio Fialho de Vargas adquiriu uma área de duas léguas quadradas (8.712 hectares) do Governo Provincial na década de 1860. Essas terras estavam valorizadas devido à expansão da colonização no vale do Taquari e no município de Santo Antônio da Patrulha, em direção à povoação de Santa Bárbara. Diante da possibilidade de perderem suas posses e o acesso aos ervais de uso comum, em 1867, os ervateiros, instalados na área adquirida por Antônio Fialho de Vargas, enviaram correspondência à Câmara

36 MOTTA, Márcia. Nas fronteiras..., op. cit. 
de Vereadores de Taquari, em que solicitavam a destinação de uma légua quadrada para seu usufruto comum. A preservação de áreas exploradas em uso coletivo por lavradores estava prevista no Regulamento de 1854, onde se lia o seguinte:

Art. $5 .^{\circ} \$ 4 .^{\circ}$ Os campos de uso comum dos moradores de uma ou mais freguesias, municípios ou comarcas seráo conservados em toda a extensão de suas divisas e continuarão a prestar o mesmo uso, conforme a prática atual, enquanto por lei não se dispuser o contrário ${ }^{37}$.

Assim, o pedido de preservaçáo da área de uso comum estava assegurado juridicamente. Nesse caso, caberia à Presidência da Província retirar a área de usufruto coletivo dos posseiros do povoado de Santa Bárbara daquela vendida a Antônio Fialho de Vargas. No entanto, os ervateiros foram além e denunciaram as especulaçóes exercidas em torno das terras daquela região. A Câmara de Taquari, por sua vez, enviou correspondência à Presidência da Província relatando o fato:

Chegando ao conhecimento dessa Camara por conducto do Capitão João Mariano Pimentel a maneira menos justa, por que contra toda a espectativa dos habitantes, se estâo procedendo mediçóes de terrenos nas immediaçóes da povoação de Santa Bárbara, sita á margem direita do rio Taquary por forma a prejudicar os respectivos moradores do próprio logradouro publico e suas commodidades vem essa Camara submetter a consideração de V. Exa a a indeclinavel necessidade que elles tem de uma area de terreno que fica entre o arroio -Cachoeira Brava- e o -S. Jeronymo- que terá uma legua mais ou menos de

37 SECRETARIA DA AGRICULTURA do Rio Grande do Sul. Coletânea da legislaçáo das terras públicas do Rio Grande do Sul. Porto Alegre, 1961. 
extenção, a fim de que tal territorio seja exceptuada das medições que procedera Antonio Fialho de Vargas e outros, para servir de patrimonio, como reserva e recurso aquella populaçáo, composta de gente pobre e laboriosa, já no fabrico de herva matte, de que é abastecido o solo, como em madeiras para a construção, lenhas etc [...] O terreno, segundo informaçôes, é coberto de herva matte, por isso que, dos limites marcados para o centro, ainda poderá valer o triplo ou o quadruplo de outro qualquer no mesmo lugar, conseqüentemente pode acontecer que os pretendentes só tenhão em vista fazel-o medir e demarcar para se evitarem o pagamento da nação, como aconteceu com Joaquim Gregorio de Oliveira e outros nos suburbios da mesma povoação de Santa Barbara e terrenos adjacentes. A exemplo, pois do que se tem dado na Crus Alta de Cima da Serra, tão bem essa Camara podia fazer arrematar os respectivos hervaes, se V. Ex ${ }^{\mathrm{a}}$. concedendo-lhe essa authorisação, julgasse conveniente uma tal providencia.

Illmo. e Exmo Senr. Dr. Francisco Ignacio Marcondes Homem de Mello, Presidente da provincia $^{38}$.

Os ervateiros do povoado de Santa Bárbara não conseguiram assegurar a preservação da área que ocupavam como uma reserva de uso comum, mas sua pressão sobre os órgáos públicos fez com que o terreno em questão não fosse comercializado até, pelo menos, o ano de 1895. No inventário post-mortem de Antônio Fialho de Vargas, consta uma área de 4.329 hectares, próxima ao povoado de Santa Bárbara, ao lado das terras do herdeiro Joaquim

Correspondência da Câmara Municipal de Taquari de 1867, nº 05. AHRS. 
Fialho de Vargas ${ }^{39}$. Essa família ainda possuía o título sobre a mesma área após 22 anos da reivindicação daqueles moradores, mas, até aquele momento, não a colonizara. Como se tratava de negociantes dinâmicos, esse enorme interregno é indicativo da pressão exercida pelos ervateiros para a preservaçáo dos ervais de uso comum. Por isso, essa reivindicação adiou a colonização daquele erval por um longo período.

\section{O homem livre e pobre nas fontes do Brasil oitocentista}

Para finalizar, como forma de instigar colegas historiadores em formação, passo a apresentar algumas das principais fontes que podem ser utilizadas em pesquisas sobre os homens livres e pobres no Século XIX para o caso paraibano. Seus dois grupos principais de fontes, ainda pouco exploradas pela historiografia, são a documentação da Justiça e das instâncias administrativas do estado da Paraíba ${ }^{40}$.

No Século XIX, os processos judiciais seguiam os cursos processuais das açôes ordinárias e sumárias ${ }^{41}$. As ações ordinárias tinham suas raízes no Direito moderno e resolviam o litígio 'por inteiro', sem deixar pendências para serem resolvidas em um novo processo. Essas açóes processuais eram mais longas, na medida em que se assegurava a chance de prova e de defesa plenas entre as partes. Já as açóes sumárias, que receberam maior espaço no Século XIX, eram constituídas pelos processos de tramitação mais simples e rápida, para evitar a mora processual. As açôes do curso processual sumário operavam apenas uma parte do conflito, que exigia uma resolução mais rápida, sendo que algumas questôes eram reservadas para futuros processos em açôes de cur-

39 Inventário post-mortem do Cartório de Orphãos e Ausentes de Taquari no 475, de 1895. APERS.

40 Para se aprofundar mais sobre a documentação utilizada na historiografia especializada em História Agrária e seu potencial de pesquisa, consultar: MOTTA, Márcia e GUIMARÃES, Elione (orgs.). Propriedades e disputas: fontes para a história do Oitocentos. Guarapuava: Unicentro; Niterói: EDUFF, 2011.

41 No foro civil, reconheciam-se cinco maneiras principais de processar e com diferenças entre si: ação de juramento de alma, de assinação de dez dias, executiva, ordinária e sumária. CORDEIRO, Carlos Antônio. $\mathbf{O}$ assessor forense ou todas as açóes conhecidas no foro brasileiro - Tomo II. Rio de Janeiro: Laemmert, 1864. 
so processual ordinário. No caso das disputas que envolvem os homens livres e pobres, em suas disputas pela posse da terra, os principais tipos de açóes ordinárias eram os processos de esbulho (força nova, força velha e obra nova), os processos de embargo e os processos sumários propriamente ditos.

Os processos de ação ordinária ocorriam em casos de litígios entre duas partes, ligados, com frequência, a dívidas realizadas por meio de hipoteca de imóveis e geralmente aplicados a casos de empréstimos em que os acordos de pagamento eram descumpridos. A análise do uso da terra em hipotecas contribui para que se possa investigar a dinâmica de legitimação da propriedade na sociedade brasileira ao longo desse período. Mas as fraudes constantes nos títulos ou documentos de posse utilizados nas hipotecas, no ato da entrega do imóvel, que geravam a contestação de terceiros, também podem demonstrar a ação dos homens livres e pobres na defesa de suas posses de terras, asseguradas pela Lei de Terras de 1850.

Os processos de ação sumária foram, geralmente, aplicados em questóes de terras, nos casos em que o acusador possuía um documento ou título que atestasse sua propriedade sobre a área contestada. Na ação sumária, o possuidor de uma área de terras, ou que se dizia dono do imóvel, apresentava suas provas de propriedade sobre as áreas em litígios. $\mathrm{O}$ cruzamento desses documentos com outros sobre a área em litígio permite ao historiador investigar as fraudes no processo de apropriação da terra. Essa seria outra açáo a que os homens livres e pobres recorreram para defender seus interesses.

As ações de esbulho eram encaminhadas, nos casos de tomada arbitrária da posse ao seu possuidor, em prejuízo do seu direito de propriedade. Esse processo judicial poderia ser encaminhado como "nunciação de obra nova" ou "força nova", quando o esbulho tinha sido feito antes de um ano e um dia. Quando o esbulho havia sido cometido num espaço temporal maior, o auto passava a ser encaminhado como ação de "força velha". A nunciação de obra nova foi a ação mais frequente nos casos de litígios sobre a propriedade da terra. A nunciação de obra nova foi utilizada, 
principalmente, nos casos de "arranchamentos com princípio de cultura", nas transposiçóes de divisas e na apropriação de recursos extrativos, como foi o caso da madeira e da erva-mate no sul do Brasil. Os homens livres e pobres não foram passivos àquele processo de expansão da fronteira agrária. Eles questionaram os direitos de propriedade dos grandes grileiros. Os indícios presentes nas açôes de esbulho contribuem para a análise da resistência do campesinato brasileiro do Século XIX.

Os processos de embargo também oferecem muitos dados a respeito dos homens livres e pobres. Eles eram encaminhados quando ocorresse alguma alteraçáo no estado de um bem, geralmente a propriedade da terra, e seguiam o curso processual das açôes sumárias. $\mathrm{O}$ processo de embargo foi empregado somente na fase inicial do ato possessório. Eles foram utilizados com frequência nas disputas de terras, geralmente utilizados no momento inicial de uma 'ocupação criminosa', como a preparação de um roçado para o plantio, a construçáo de alguma benfeitoria relativa à posse da terra e nos casos de derrubada de florestas ou extraçáo de algum de seus recursos. Foi no processo de embargo que os grandes fazendeiros encontraram o caminho mais eficaz para desconstruir a legitimidade da ocupaçáo do pequeno posseiro, o que lhes assegurava a apropriação das terras públicas ${ }^{42}$.

O processo de manutençáo de posse é, também, outra documentação judicial utilizada com frequência no Século XIX, com potencial analítico para a investigação histórica. Tratava-se de um tipo de processo que era encaminhado diante da ameaça de terceiros ao direito de propriedade sobre um bem, geralmente nos casos de usufruto da terra e de descumprimento das cláusulas de alforria ${ }^{43}$. Portanto, as fontes judiciais podem contribuir para a análise de um conjunto de conflitos que, mesmo não constituindo um movimento mais amplo, lograram retardar ou barrar, no plano local, as mudanças estruturais provocadas pela expansáo do latifúndio e da grilagem no campo.

42 MOTTA, Márcia, Nas fronteiras..., op. cit, p. 69.

43 GUIMARÃES, Elione Silva. Terra de preto: usos e ocupação da terra por escravos e libertos (Vale do Paraíba mineiro, 1850-1920). Niterói: EDUFF, 2009. 
Os documentos dos Poderes Executivo e Legislativo constituem outro grupo de fontes importantes para a investigaçáo dos homens livres e pobres. Seus principais fundos documentais, no Período Imperial, dizem respeito às atas da Câmara Geral dos Deputados e das Câmaras de Vereadores e os relatórios ministeriais e dos presidentes de província.

As atas da Câmara Geral dos Deputados, produzidas a partir de suas sessóes, trazem informaçóes importantes sobre os homens livres e pobres, na medida em que relatam os debates em torno de questôes como as políticas de terras, de colonização, da transição ao trabalho livre e dos projetos de modernização da agricultura no Século XIX.

Os relatórios ministeriais também são, entre as fontes oficiais, um grupo documental importante para a análise dos homens livres e pobres, porquanto apresentam indícios sobre o grupo e temas diretamente relacionados a eles. Os relatórios do Ministério da Agricultura trazem informaçóes sobre a aplicação da Lei de Terras, a criaçáo de colônias com imigrantes e 'nacionais', a emancipaçáo dos cativos, entre outros temas. Já os relatórios do Ministério da Justiça trazem informaçóes sobre a 'tranquilidade pública' nas diversas regióes do Brasil, que permitem ao historiador investigar alguns atos locais que, mesmo náo sendo um movimento social mais amplo, provocaram um impacto político importante naquela sociedade. Na mesma direçáo dessas fontes, estão os relatórios de presidentes de província, em que o historiador encontrará as mesmas temáticas, muitas das quais, em plano local, estáo ainda mais detalhadas. Os relatórios ministeriais e os relatórios de presidentes de província encontram-se disponíveis para pesquisa nos arquivos públicos estaduais, no sítio eletrônico da Universidade de Chicago (CRL/LAMP) ${ }^{44}$.

As atas das câmaras municipais, por sua vez, são as fontes mais ricas sobre o universo rural brasileiro no Século XIX. Elas oferecem um grande número de informaçóes sobre os homens livres e pobres e outras discussóes relacionadas ao tema. Nas câmaras municipais, existe um número maior de informaçôes sobre os 
estado da "tranquilidade pública", da questão servil, dos "trabalhadores nacionais", sobre as "terras em usufruto" de comunidades locais, entre outros. Em minha dissertação de Mestrado, foi nas atas das câmaras municipais que encontrei o maior número de informaçôes sobre os invisiveis da terra ${ }^{45}$.

\section{REFERÊNCIAS}

ABREU, Marcelo de Paiva; LAGO, Luiz Aranha Correa do. A economia brasileira no Império 1822-1889. Rio de Janeiro: Texto para discussão n.584, Departamento de Economia, PUC -Rio, novembro de 2010.

CANDIDO, Antônio. Os parceiros do Rio Bonito: estudo sobre o caipira paulista e a transformação dos seus meios de vida. Rio de Janeiro: José Olympio Editora, 1964.

CARDOSO, Fernando Henrique. Capitalismo e escravidáo no Brasil Meridional: o negro na sociedade escravocrata do Rio Grande do Sul. Rio de Janeiro: Paz e Terra, 1977.

CASTRO, Hebe Maria Mattos de. Ao sul da história: lavradores pobres na crise do trabalho escravo. São Paulo: Brasiliense, 1986.

CHRISTILLINO, Cristiano Luís. Estranhos em seu próprio cháo: o processo de apropriaçóes e expropriaçóes de terras na Província de São Pedro do Rio Grande do Sul (o Vale do Taquari no período de 1840-1889). São Leopoldo: Dissertação de Mestrado em História/UNISINOS, 2004.

CHRISTILLINO, Cristiano Luís. Litígios ao sul do Império: a Lei de Terras e a consolidaçáo política da Coroa no Rio Grande do Sul (1850-1880). Niterói: Tese de Doutorado em História/UFF, 2010. 
CORDEIRO, Carlos Antônio. $\mathbf{O}$ assessor forense ou todas as açóes conhecidas no foro brasileiro - Tomo II. Rio de Janeiro: Laemmert, 1864.

CORRESPONDÊNCIA DA CÂMARA MUNICIPAL DE TAQUARI DE 1867 no 05. (Arquivo Histórico do Rio Grande do Sul - AHRS)

CUNHA, Euclides. Os Sertóes, v. 2. Campanha de Canudos. São Paulo: Aguillar, 1966.

DEAN, Warren. Rio Claro: um sistema brasileiro de grande lavoura 1820-1920. Rio de Janeiro: Paz e Terra, 1987.

DREHER, Martin N.; ALTMANN, Friedholt. Os primórdios da Colônia Teutônia no Rio Grande do Sul. In: Estudos Leopoldenses, Série História, v.2, n.2, 1998.

FARINATTI, Luís Augusto Ebling. Sobre as cinzas da mata virgem: lavradores nacionais na Província do Rio Grande do Sul (Santa Maria, 1845-1880). Porto Alegre: Dissertaçáo de Mestrado em História/PUCRS, 1999.

FOLETTO, Arlene Guimarães. Dos campos junto ao Uruguai aos matos de cima da serra: a paisagem agrária na Paróquia de São Patrício de Itaqui (1850-1889). Porto Alegre: Dissertação de Mestrado em História/UFRGS, 2003.

FRAGOSO, João Luís. Economia brasileira no Século XIX: mais do que uma plantation escravista-exportadora. In: LINHARES, Maria Yedda (org.). História geral do Brasil. 2.ed. Rio de Janeiro: Ed. Campus, 1996.

FRANCO, Maria Sylvia de Carvalho. Homens livres na ordem escravocrata. São Paulo: Kairós, 1983. 
GARCIA, Graciela Bonassa. Terra, trabalho e propriedade: a estrutura agrária da campanha rio-grandense nas décadas finais do período imperial (1870-1890). Niterói: Tese de Doutorado em História/UFF, 2010.

GUIMARÁES, Elione Silva. Terra de preto: usos e ocupações da terra por escravos e libertos (Vale do Paraíba mineiro, 18501920). Niterói: EDUFF, 2009.

INVENTÁRIO POST-MORTEM DO CARTÓRIO DE ORPHÁOS E AUSENTES DE TAQUARI No 475, de 1895 (Arquivo Público do Estado do Rio Grande do Sul - APERS).

LANG, Guido. A Colônia Teutônia: história e crônica (18581908). São Leopoldo: Rotermund, 1992.

MAGALHÃES, Dóris Rejane Fernandes. Terras, senhores, homens livres, colonos e escravos na ocupaçáo da fronteira no Vale dos Sinos. São Leopoldo: Tese de Doutorado em História/ UNISINOS, 2003.

MOTTA, Márcia; GUIMARÃES, Elione (orgs.). Propriedades e disputas: fontes para a história do oitocentos. Guarapuava: Unicentro; Niterói: EDUFF, 2011.

MOTTA, Márcia Maria Menendes. Jogos da memória: conflitos de terra e amnésia social. Tempo, n.6, 1998, p.183-198.

MOTTA, Márcia. Nas fronteiras do poder: conflito e direito a terra no Brasil do Século XIX. Rio de Janeiro: Arquivo Público do Estado do Rio de Janeiro/Vício de Leitura, 1998.

MUNHOZ, Cláudia. A Associaçáo Comercial do Rio Grande de 1844 a 1852: interesses e atuação representativa do setor mercantil. São Leopoldo: Dissertação de Mestrado em História/ 
UNISINOS, 2003.

\section{RELATÓRIO DO PRESIDENTE DA PROVÍNCIA DO RIO GRANDE DO SUL DE 1859.}

RIBEIRO, José Iran. Quando o serviço os chamava: milicianos e guardas nacionais no Rio Grande do Sul (1825-1845). Santa Maria: Editora da UFSM, 2005.

SECRETARIA DA AGRICULTURA RS. Coletânea da legislaçáo das terras públicas do Rio Grande do Sul. Porto Alegre, 1961.

SOUZA, Laura de Mello e. Desclassificados do ouro: a pobreza mineira no Século XVIII. Rio de Janeiro: Ediçôes Graal, 1982.

THOMPSON, Edward Palmer. As peculiaridades dos ingleses e outros artigos. Campinas: Ed. da UNICAMP, 2001.

THOMPSON, Edward Palmer. Costumes em comum. São Paulo: Cia. das Letras, 1998.

THOMPSON, Edward Palmer. Senhores e caçadores: a origem da Lei Negra. Rio de Janeiro: Paz e Terra, 1987.

WANDERLEY, Maria de Nazareth Baudel. Raízes históricas do campesinato brasileiro. In: Anais do XX Encontro Anual da ANPOCS, Caxambu, 1996.

ZARTH, Paulo Afonso. Do arcaico ao moderno: as transformaçôes do Rio Grande do Sul rural no Século XIX. Ijuí: Editora da Unijuí, 2002.

ZARTH, Paulo Afonso. História agrária do Planalto Gaúcho (1850-1920). Ijuí: Fidene-Unijuí, 1997. 